Industry-specific CSR: analysis of $\mathbf{2 0}$ years of research

\begin{tabular}{|r|l|}
\hline Journal: & European Business Review \\
\hline Manuscript ID & EBR-06-2015-0058.R1 \\
\hline Manuscript Type: & Article \\
\hline Keywords: & literature analysis, CSR, industry, business ethics, research \\
\hline & \\
\hline
\end{tabular}

SCHOLARONE ${ }^{m}$

Manuscripts 


\title{
Industry-specific CSR: Analysis of 20 years of research
}

\begin{abstract}
Purpose - This study analyzes the literature on industry-specific corporate social responsibility (CSR) practices.

Design/methodology/approach - Using a multiple keyword search, we identified 302 articles reporting on such practices, published in 99 different academic journals between 1995 and 2014. We analyzed these articles to map the CSR literature, identify which industries have been under greater scrutiny, and distinguish trends in the most researched industries.

Findings - Our findings indicate that the CSR studies are very unevenly distributed and that the issues studied and the methods used vary widely across industries. We also map this field of study and propose suggestions on where research on industry-specific CSR should go in the future.
\end{abstract}

Originality/value - We provide the first extensive, systematic analysis of the industry-specific CSR literature. Our research adds value to the literature by highlighting the key issues investigated as well as those that require further inquiry.

Keywords: literature analysis, Corporate Social Responsibility, industry, business ethics, research. 


\section{Introduction}

In recent decades, scholars, practitioners, governments and society have become increasingly interested in the ways companies behave towards their internal and external stakeholders and their environment (Freeman, 1984; Carroll, 1991, 1999; Campbell, 2007; Claydon, 2011; Aguinis and Glavas, 2012; Beschorner et al., 2013a; Painter-Morland and ten Bos, 2011; Hah and Freeman, 2014). This interest has led to the emergence of several new concepts such as Corporate Social Responsibility (CSR) Corporate Responsibility (CR), business ethics and sustainable development, which have become integral to understanding the global organization of the $21^{\text {st }}$ Century. The shared interest of governments and businesses in the issue of company responsibility has also led to global initiatives to promote responsible business behavior, such as the UN Global Compact, the European Alliance for CSR, Global Reporting Guidelines (GRI), the World Bank Council for Sustainable Development and the ISO 26000 (responsible practices) standard.

McWilliams and Siegel (2001) consider CSR to be the point where a firm goes beyond its interests and legal compliance and acts to advance the social good. Recently, the European Commission defined CSR as "the responsibility of enterprises for their impacts on society" (2011, p. 6) and invited firms to implement "a process to integrate social, environmental, ethical, human rights and consumer concerns into their business operations $[\ldots]$ with the aim of maximizing the creation of shared value for their owners/shareholders and for their other stakeholders and society at large" $(2011$, p. 6). This conceptualization of CSR is in line with the stakeholder approach, which views CSR as an extension of corporate governance, where a firm's duties extend beyond its shareholders to a broader group of stakeholders (Sacconi, 2011). Aguinis (2011, p. 855) proposed that CSR refers to "context-specific organizational actions and policies that take into account the stakeholders' expectations and the triple bottom 
line of economic, social, and environmental performance." This definition suggests that the context in which firms operate influences CSR practices enormously.

Indeed, by definition, corporate responsibility is highly context dependent. Although companies design their CSR practices individually, in so doing they are guided by the formal and informal institutional environment of the countries in which they operate (Aguinis and Glavas, 2012)-“the rules of the game” (North, 1990; Scott, 1995)-as well as their consumers, suppliers, partners and other actors (Beschorner et al., 2013b). In particular, the industry or sector in which a firm operates determines CSR practice, as industries have their specific rules, norms, practices and trends. However, although the firm's industry is critical to CSR practice, an analysis of the academic literature on CSR from an industry perspective reveals important variations in the interest that different industries attract. As one would expect, some industries have come under scrutiny because of public scandals, such as the notorious collapse of Enron, the American energy company. Particular attention has been paid to the petroleum, financial, footwear and textile industries (e.g. Burcielli et al., 2009; Wu and Shen, 2013). Other industries attract interest because they deal with essential consumer needs, like the food and beverage industries (Lamberti and Lettieri, 2009; Hartmann, 2011) or the pharmaceutical industry (Flanagan and Whiteman, 2007; Hemphill, 2010). Conversely, researchers have paid little interest to industries such as aerospace, plastics or rubber.

In this study, we investigate the literature on industry-specific CSR practices. The research questions that we aim to answer are the following: 1) On which industries has CSR research focused to date? 2) What industry-specific CSR issues have been investigated in the most studied industries? 3) How have attitudes to CSR developed in different industries, in view of Frederick's (2006) analysis of CSR stages? 4) What do the various CSR practices in different industries tell us about the different motives behind CSR? 5) What direction should industryspecific CSR research take in the future? To date, no study has investigated CSR research in 
detail from the perspective of different industries or sectors, although there have been a number of reviews of the CSR literature, particularly in the last few years (see Salzmann et al., 2005; Lee, 2008; Carroll and Shabana, 2010; Aguinis and Glavas, 2012). This is rather surprising, because academics and practitioners increasingly agree that CSR practices are context-specific (Sharma and Henriques, 2005; Stevens et al., 2005; Aguinis, 2011), and shaped by industry conditions (Isaksson et al., 2014). In this study we aim to contribute to the academic literature by providing an analysis of the research focusing on CSR practices in specific industries and by outlining avenues for future research.

To analyze the industry-specific CSR literature we searched for academic articles on this topic through The Web of Science Social Science Citation Index-SSCI. This search generated a list of 302 articles, which we coded and analyzed. This analysis revealed how research in this area has evolved, identified key academic outlets for such research and allowed us to rank industries in terms of how much research they have stimulated. We were then able to map the research field and indicate the gaps that need filling in the future.

The article is organized as follows. The next section presents an overview of the key approaches to studying CSR. We then provide an overview of the literature focusing on CSR practices from an industry perspective, before explaining the methods and the data used in our study. Next, we present and discuss our findings. Finally, we outline the major contributions of our work, its limits, implications and future research directions.

\section{Key approaches to studying CSR}

In his conceptualization of CSR, Frederick (2006) distinguished between $\mathrm{CSR}_{1}, \mathrm{CSR}_{2}$, and $\mathrm{CSR}_{3}$. From the $\mathrm{CSR}_{1}$ perspective, corporate social responsibility is based on the belief that business should contribute to the betterment of society, which grew out of a longstanding 
commitment to corporate philanthropy dating from the $19^{\text {th }}$ century (Frederick, 2006, p. 36). Frederick argued that $\mathrm{CSR}_{1}$ was not clearly institutionalized, and that though it made strong moral claims, its exact moral underpinnings were not agreed on. In many ways, $\mathrm{CSR}_{1}$ was the kind of social responsibility that could be managed at arms-length from everyday business operations. In fact, as we shall see below, some business practitioners believed that corporations should focus on profitmaking, and that duties towards society were a private responsibility, especially since the moral underpinnings of company-wide CSR were not clearly established.

Milton Friedman, a famous example of this approach (Friedman, 1962), wrote an article in the New York Times Magazine in 1970 in which he concluded that "there is one and only one social responsibility of business: to use its resources and engage in activities designed to increase its profits so long as it stays within the rules of the game, which is to say, engages in open and free competition without deception or fraud" (p. 126). He believed that managers who use company resources to support societal causes were in fact misappropriating shareholder property. Despite its popularity at the time, especially among practitioners, Friedman's view of CSR has been extensively criticized, in particular his assumption that there is no positive link between socially responsible behavior and financial performance (Bruyaka et al., 2013). Since Friedman's writings, the issues of firm responsibility and the response of markets and society to business behavior have become central, particularly in the last two decades. Frederick (1994) argued that $\mathrm{CSR}_{1}$ gave way to $\mathrm{CSR}_{2}$, which he defines as “corporate social responsiveness". Whereas philosophical overtones characterized $\mathrm{CSR}_{1}$, $\mathrm{CSR}_{2}$ focused more on the practical aspects of making corporations respond to tangible social forces in its environment. $\mathrm{CSR}_{2}$ was thus more pragmatic than $\mathrm{CSR}_{1}$. It emphasized the tools, techniques, organizational structures and behavioral systems that a socially responsive 
company requires (Frederick, 2006, p. 43). This CSR perspective also initiated empirical research on CSR.

However, in the shift from $\mathrm{CSR}_{1}$ to $\mathrm{CSR}_{2}$ the link between the moral dimensions of $\mathrm{CSR}_{1}$ and the managerial dimensions of $\mathrm{CSR}_{2}$ remained unclear (ten Bos and Dunne, 2011). Frederick (1994) proposed that a shift to $\mathrm{CSR}_{3}$ was imminent. He predicted (1994, p. 162) that the era of $\mathrm{CSR}_{3}$, "will clarify both the moral dimensions implied by $\mathrm{CSR}_{1}$ and the managerial dimensions of $\mathrm{CSR}_{2}$ ". Frederick (2006, p. 90) described $\mathrm{CSR}_{3}$ as "corporate social rectitude"an approach acknowledging that ethics is central to management decisions and policies.

In the 10 years since Frederick analyzed the maturing of the CSR concept, the literature indeed reflects this shift to $\mathrm{CSR}_{3}$. Papers demonstrate a concern for both moral correctness and appropriate policies and programs. The increased interest in this field has led to the emergence of a particular research field focusing on business ethics and CSR, and to the establishment of academic journals especially dedicated to responsible business practices. These include the Journal of Business Ethics, Business Ethics Quarterly, Business Ethics: A European Review, and Social Responsibility Journal. The growing body of literature has led to the emergence of conceptual frameworks analyzing the complex phenomenon of firm responsibility. Three of the various approaches proposed in the academic literature have particularly influenced CSR studies, precisely because they seem to combine the normative and managerial dimensions of CSR. These are the stakeholder framework, developed by Freeman (1984); Carroll's (1991) CSR pyramid; and the recent shared value approach (Porter and Kramer, 2006).

Freeman was one of the first academics who rejected Friedman's perception of company responsibility. Freeman's $(1984 ; 1994)$ and Freeman et al.'s $(2010)$ main thesis is that an organization should be managed in the interest of all people, organizations and groups within and around it, and not just in the interest of shareholders. Drawing on several streams of 
literature such as corporate planning, systems theory and corporate social responsibility, Freeman argues that existing management theories are not equipped to address "the quantity and kinds of change which are occurring in the business environment" (Freeman, 1984, p. 5), such as takeovers, foreign competition, supranational agencies, activism, consumer movements, increasing environmental concerns and Information and Communication Technology (Laplume et al., 2008). These environmental shifts are occurring among both internal stakeholders (owners, managers, customers, suppliers, employees) and external stakeholders (governments, environmentalists, special interest groups, the media, competitors, consumer groups), and it is important to consider these groups when designing corporate strategy and shaping corporate behavior (Freeman, 1984). The consideration of stakeholder interests is seen as playing an instrumental role in enhancing performance (Laplume et al., 2008).

Carroll (1991, p. 40) defined CSR as a list of normative responsibilities that all corporations have towards society. Building on his prior work (Carroll, 1979), he developed the "Pyramid of CSR", a four-part comprehensive model that distinguishes between four aspects of the social world: economic, legal, ethical and philanthropic. The pyramid includes dimensions that society requires from corporations and others that are simply preferred. In the revised version of the 1991 model, Schwartz and Carroll (2003) include three types of ethical standard in the model - conventional (i.e. formal codes of conduct), consequentialist (utilitarianism or promoting the good of society), and deontological (moral rights and justice). Activities that take place despite the company being aware that they conflict with moral principles, and those that aim to produce a net benefit for the corporation rather than for stakeholders, fall outside the ethical domain (Schwartz and Carroll, 2003).

Carroll's (1991) model is one of the earliest models of the structure of responsibilities within a corporation and is still widely used (Claydon, 2011), even though it has been criticized. One 
of the major criticisms is the fact that, according to the model, economically weak firms are less likely to engage in CSR as they have fewer resources (Campbell, 2007). Moreover, the model does not integrate the advantages of CSR for the firm (Campbell, 2007).

Following the global financial and economic crisis of 2008, research on CSR has blossomed. Academics have examined the roots of the crisis and offered guidelines on how to avoid such phenomena and act as a good corporate citizen. According to Porter and Kramer (2006) the solution to the problem that capitalism is facing "lies in the principle of shared value, which involves creating economic value in a way that also creates value for society by addressing its needs and challenges." (p. 64). According to these authors, shared value is different from social responsibility, philanthropy and sustainability; it is rather a new way to achieve economic success. The purpose of the corporation must be redefined as creating shared value, not just profit per se. Shared value is defined as "policies and operating practices that enhance the competitiveness of a company while simultaneously advancing the economic and social conditions in the communities in which it operates" (Porter and Kramer, 2006, p. 66). These authors argue that creating shared value (CSV) should supersede CSR in guiding corporate investments, because while CSR programs focus on reputation and have only a limited connection to the firm, CSV is integral to a company's profitability and competitiveness.

To sum up, CSR literature has grown considerably since the 1970s. Different frameworks have been proposed to study CSR, and interest in the ways CSR is practiced in different industries has increased. This last point will be outlined in the following section. 


\section{CSR in different industries: an overview of the literature}

Among the various actors who should play a leading role in addressing social responsibility and sustainability, business organizations are often considered as pivotal (Fairbrass and Zueva-Owens, 2012), because their practices affect production and consumption within society (Fairbrass, 2011). However, business organizations do not act independently. At the macro-level, they are influenced by the actions of governments and supra-national agencies. At the meso-level, they are impacted by the rules of the game in their industry. Although CSR has been discussed and researched for decades, according to McWilliams et al. (2006), it is still an emerging area of inquiry. Moreover, CSR research is often characterized as fragmented (Aguinis and Glavas, 2012). In particular, one aspect of CSR research that needs further investigation is the relationship between CSR practices and the sector of activity (Beschorner et al., 2013b). While the academic literature has acknowledged the impact of the industry on CSR (Rowley and Berman, 2000; Hendry, 2006; O'Connor and Shumate, 2010; Beschorner et al., 2013a), research on industry-specific CSR practices is still incomplete, unbalanced and fragmented.

Yet most findings to date concur that the particular industry significantly affects CSR activities. Hendry (2006) argues that activists first select the issue and industry before targeting a specific firm. This highlights the importance of industries in the study of CSR. Firms in the same industry share many stakeholders (for example they compete for the same consumers). In addition, policymakers design regulations for specific industries, which means that firms operating in the same industry face the same constraints (O'Connor and Shumate, 2010), such as environmental or labor regulations. Industry characteristics that make firms more likely to engage in CSR include the following: 1) being closer to consumers in the value chain (e.g. specialty retailers); 2) using environmental resources; and 3) heavy industry that 
can harm communities considerably (Rowley and Berman, 2000). According to Hendry (2006), changes in CSR by prominent corporations are likely to spread across the field with other firms mimicking such behavior. O'Connor and Shumate (2010) argue that firms in the same industry may use similar CSR communication to influence similar stakeholders.

Findings suggest that CSR practices differ depending on the industry's position in the value chain. Industries further up the value-chain focus on employee safety, ethical business practices, and environmental stewardship, whereas industries closer to customers tend to focus on philanthropic and educational CSR practices (O'Connor and Shumate, 2010). O'Connor and Shumate show that CSR communication differs significantly across industries, depending on the type of value chain. The cross-sector study by O'Connor and Shumate (2010) shows that corporations within the chemical, mining, petroleum and utilities industries focus on three of the four levels of Carroll's (1991) CSR pyramid in their communication: 1) philanthropy, 2) ethical and 3) economic responsibilities. In contrast, firms closer to the consumer in the value-chain, such as those in commercial banking, merchandising, hotels, casinos, resorts, specialty retailing and telecommunications, communicate solely on their philanthropic responsibilities. These findings suggest that firms within the same industry or in a similar value-chain position mimic each other's CSR communication, which negates the idea that CSR allows firms to achieve a competitive advantage by distinguishing themselves from others (Porter and Kramer, 2006). Based on an analysis of CSR disclosures by 50 American companies, Holder-Webb et al. (2008) conclude that the industry affects content, emphasis, and reporting format choices. It thus appears that the industry with the closest ties to the consumer-base and the community (food retail in this study) may disclose most CSR information. Conversely, B-to-B industries report much less CSR information.

Focusing on charitable activities, Roberts (1992) argues that the industry influences CSR activity. Furthermore, Useem (1988) points out that industries with high levels of public 
contact, such as retailing, banking and insurance, create a greater need for positive image than low contact industries such as mining or primary metals. Some industries are more vulnerable than others are to public opinion, and so they use charitable giving as a means of inoculating themselves against a negative image (Amato and Amato, 2012). Amato and Amato (2007) conducted a cross-sectional study of corporate giving covering a broad spectrum of industries. Their results indicate substantial industry effects, with industry dummy variables explaining more than $20 \%$ of the variation in charitable contribution. These industry effects are attributed to product features or other market attributes, which make all firms in a given industry vulnerable in terms of public relations. Moreover, Brammer and Millington (2005) show that the beneficial effects of charitable giving vary significantly across industries.

To summarize, research findings suggest that industries and sectors greatly affect CSR activities. However, there is still no overall understanding of which industries have been researched or of the key findings from specific industries. This study aims to enhance such understanding by systematically reviewing the industry-specific CSR literature.

\section{Method and data generated}

In line with Dabic et al. (2014) and because, to the best of our knowledge, our study is the first industry-level analysis of the CSR literature, we decided not to restrict our research to specific journals, but to include all the outlets indexed and abstracted in the Social Science Citation Index (SSCI). Moreover, the SSCI database includes the most relevant journals for CSR, sustainable development and business ethics research such as the Journal of Business Ethics, Business Ethics Quarterly, Business Ethics: A European Review, Corporate Social Responsibility and Environmental Management and Business Strategy and the Environment. The SSCI database also includes English abstracts of papers published in other languages. 
We conducted a general search for CSR-related and industry-related terms. We searched for "corporate social responsibility" or "CSR" and "business ethics" or "ethic" and "industry" or "sectors". We used the wildcard "*" to ensure we obtained all possible combinations of the lexeme "corporate responsibility", "industry" and "sector" (e.g. "responsibility, responsible", industries", “industry”, “industrial”, “sector”, “sectors”, “sectorial”).

We concentrated on terms related to CSR and business ethics, including related terms in the literature. We drew on Carroll's (1999) analysis of the evolution of the CSR concept to identify these related terms. In the 1970s, at the beginning of the concept's development, typical subheads related to CSR were: corporate responsibility, social responsibility, social action, public service, corporate citizenship, public responsibility, and social responsiveness (Carroll, 1999, p. 281). In the 1980s, CSR research started to splinter into alternative concepts and themes such as corporate social responsiveness, corporate social performance (CSP), public policy, business ethics and stakeholder theory/management (Carroll, 1999, p. 284).

In the 1990s, Wood's refinement of the CSP concept (Wood, 1991) emphasized corporate social responsiveness, and highlighted processes such as environmental assessment, stakeholder management and issues management (Carroll, 1999, p. 289). This led Carroll to include the term "corporate citizenship" in his formal definition of CSR. Carroll found that by the end of the 1990s, the following research areas were considered important within the broader "business and society" field (in order of importance): business ethics, international social issues, business and society, corporate social performance, environmental issues, theory/research methods development, issues within corporations, strategic issues, corporate governance, and stakeholders (Carroll, 1999, p. 291). Since then, "sustainability" has also emerged as an important umbrella concept for a wide variety of CSR and business ethics issues (Amidi and Bienstock, 2014). 
Studies of ethical sustainability highlight the importance of simultaneously managing "the triple bottom-line" of people, planet and profit (Montiel and Delgado-Ceballos, 2014). Social and environmental factors, as well as ethics and governance, stakeholder management, and CSP are central to the "sustainability" construct. Since we are satisfied that the CSR research areas mentioned above also cover the sustainability construct, we did not include "sustainability" as a separate search term. Moreover, we wanted to avoid including in our sample articles that cover only "business sustainability", dealing with the longevity of the firm rather than with ethical and CSR issues.

We conducted two steps searches in the Social Science Citation Index (Web of Science) and then extracted tables using QDA Miner. Finally, we extracted from the SSCI a list of papers with citations focusing on industry-specific CSR. This database granted access to homogenous information, while controlling the quality of academically relevant contributions. We analyzed 20 years of data to find the developments that have shaped the current state of corporate social responsibility and business ethics in specific sectors and industries, and to study research trends and trajectories in this area. The timescale was therefore limited to the period between January 1995 (when the first paper was published) and December 2014. The search was conducted on the $5^{\text {th }}$ February 2015 and a table with authors, paper titles, journals information, author keywords and abstract was formed in one excel document. The extraction of articles and QDM (Wordstata 7) analysis took place between 5 and 20 February 2015. The document type selected was "article". The search yielded a list of 302 academic articles once we deleted duplicates. We reviewed the list manually to ensure that the results were valid and the articles correctly classified.

After selecting the articles, we conducted a basic descriptive statistics analysis to understand the field of study better in terms of quantity of papers published per year, authors, subject areas and authors' origins. Apart from our statistical processing of numerical data, we 
analyzed text fields using copyright keywords, assigned keywords and the abstract. We then conducted a content analysis of the words in the title and abstracts and keywords provided by authors, using both manual and computer-aided checks to ensure the procedure was reliable. For our analysis, we used Wordstat 6.1 software. This software has been used in more than 300 articles in different academic fields, including business and management. For example, Gray et al. (2004) analyzed annual reports of UK and Finnish enterprises to identify how they communicate about intangible resources. Levy (2005) used the software to analyze the influence of senior management attention patterns on corporate global strategy. Morris (1994) analyzed computerized content analysis in management research, concluding that the method is appropriate. In addition, Pollach (2011) conducted a critical review of the software.

From our content analysis we identified 882 keywords provided by the authors; subject terms represented and other relevant information. We then coded the sectors and industries referred to in the articles manually, using ISIC classification, and grouped them into subcategories to facilitate analysis. We also identified a selection of representative articles (the most cited ones) that we read through and analyzed in detail.

Table 1 shows the characteristics of the sample.

\section{Insert Table 1 about here}

\section{Findings}

Our findings show that, after the first study appeared in 1995, the number of studies reporting on CSR activities in different industries gradually increased until 2008-2009, when it rose sharply, peaking in 2009 (44 articles). Since 2009, the number of articles has been stable at around 30 per year before peaking again in 2014 (see Figure 1). Although we cannot be certain, we assume that the global financial crisis triggered the significant increase in 
academic publications analyzing CSR at the end of the last decade (Aguinis and Glavas, 2012).

Despite the fact that the 302 articles in our study were published in 99 different journals, research on CSR in specific industries is concentrated in a small number of journals, with the Journal of Business Ethics accounting for almost $40 \%$ of the papers in the sample (Table 3). However, this may be because the Journal of Business Ethics publishes multiple volumes per year, whereas other journals are often restricted to one volume with four regular and one or two special issues. Other representative journals include Corporate Social Responsibility and Environmental Management, Business Ethics: A European Review, Management Decision, Journal of Economic Geography, Business Strategy and the Environment, Journal of Cleaner Production, International Journal of Hospitality Management, Business \& Society and British Food Journal (see Table 2).

\section{Insert Table 2 about here}

While authors are from different locations (see Table 3 for the 10 leading countries), Englishspeaking countries make up $59.6 \%$ of the sample, with the U.S. as the leader. When interpreting this finding we have to take account of other variables such as the size of a country, and its number of tertiary institutions and researchers. Table 3 below does not necessarily indicate that American researchers focus more on industry-specific CSR than those in other countries, given the size of the country, the population and investment in higher education. More telling is the fact that Europe seems to have yielded the vast majority of the studies (193), which points to European researchers' interest in industry-specific CSR issues.

Our search did not take into account those articles published in other languages than English and that do not provide an abstract in English, however, articles with abstracts in English were included in our sample. Moreover, our search is restricted to those outlets referenced in the ISI-Web of Science. 


\section{Insert Table 3 about here}

Authors provided 882 keywords for their papers. Those most frequently used are CSR, business ethics, social responsibility, sustainability, stakeholders, sustainable development, supply chain management, corporate governance and globalization. Table 4 shows the top 30 keywords represented in the sample. As for the industries, food is the only one that stands out among the keywords (see Table 4).

\section{Insert Table 4 about here}

With regard to conceptual models or approaches, while some authors take a specific approach, others rely on concepts or individual variables. For example, several authors study the link between social and financial performance, without grounding their work in any specific conceptual framework, although some underpinnings can be assumed. Authors who applied conceptual frameworks to their research used a variety of models. The most used frameworks in this field of CSR research are the stakeholder approach (Freeman, 1984), Carroll's (1991) CSR pyramid and the Resource-Based View (Wernerfelt, 1984; Barney, 1991).

Our analysis shows that the number of studies of specific sectors and industries varies enormously. Different industries have also been studied in different ways. Some studies focus on a single industry or on a small number of industries. These studies provide detailed accounts of industry-specific CSR. Some studies use cross-industry samples to increase the generalizability of their findings. Other cross-industry studies seek to identify differences based on industry characteristics. Finally, in some studies industry or sector is used only as a control variable.

Table 5 presents the breakdown of the sample by sector. The bulk of the research focusing on a single sector or a small number of sectors is in the secondary and tertiary sectors (see Table $5)$.

Insert Table 5 about here 
Table 6 shows the breakdown of industries in the sample, as per ISIC classification (see Table $6)$.

\section{Insert Table 6 about here}

The most researched industries are thus retail, pharmaceuticals, mining and quarrying (which includes the petroleum and gas industries), tourism, textile and clothing, food, banking, and finance and insurance. Surprisingly, some industries that one would expect to attract great interest, such as the automotive industry, restaurants, or electric power generation seem underresearched (3-4 articles published in the 20-year period). Moreover, many industries are absent from the list, such as rubber products, printing, plastic, synthetic materials, glass, air and spacecraft and related machinery, nuclear energy, wholesale, postal and courier services, publishing, legal activities and management consultancy.

After this overview of the results for our entire sample we now present key findings concerning the research on the seven industries most represented in our sample: retail, pharmaceuticals, mining and quarrying, tourism, textile and clothing, food, and banking. These findings show that different issues are scrutinized in different industries. This confirms the fact that CSR is highly context-specific.

I. Retail. Retail (15 published studies) is the most researched industry in our sample. Research on CSR in the retail industry has applied different methods: quantitative surveys, secondary data analysis and case studies. Authors have investigated issues such as ethical trade, ethical trading principles, consumer loyalty, corporate financial performance, brand trust, brand loyalty and affection, organic products, ethical labels, global value chains and global production networks. Researchers have studied British and American retailers in particular, followed by Swedish and French firms. Articles have appeared in journals such as Business Strategy \& the Environment, Journal of Economic Geography and Journal of Business Ethics (e.g., Hughes, 2005; Jones et al., 2005; Hughes et al., 2013). 
II. Pharmaceuticals. The pharmaceutical industry has attracted significant interest in recent years, because of the controversial issues of generic drugs and extraordinary pricing. Studies focusing on CSR in this industry have dealt with issues such as stakeholder response to the behavior of pharmaceutical firms, relationships with physicians, CSR drivers and industry best practices, compulsory licensing, clinical trials, reputation, patient access to drugs, orphan drugs, research and development and innovation. Methods include illustrative examples and qualitative and quantitative studies. Most of the research has appeared in the Journal of Business Ethics (e.g. Hemphill, 2010; Bruyaka et al., 2013).

III. Mining and quarrying. This category includes the extraction of coal, metals, sand, salt, peat, as well as petroleum (oil) and gas. Authors studying business ethics and CSR in this industry have mainly used qualitative methods, particularly case studies and interviews with stakeholder groups. The stakeholder approach is often the conceptual framework for this research. For the extraction of coal and other materials, case studies focus on mining companies but also on how mining projects are perceived by stakeholders. Oil and gas case studies deal with global companies operating in different settings. Topics and issues investigated include the CSR orientation of mining companies, mining ethics, environmental impact, legal responsibilities, sustainability reporting, conflicts with communities and resettlement and displacement. As for the pharmaceutical industry, most of the research has appeared in the Journal of Business Ethics (e.g. Cragg and Greenbaum, 2002; Logsdon and Wood, 2005; Yakovleva and Vazquez-Brust, 2012).

IV. Tourism. Research examining responsible business practices in the tourism and hospitality industry has appeared in specialist journals such as Journal of Sustainable Tourism, Tourism Management, International Journal of Hospitality Management and Journal of Travel and Tourism Marketing. Authors analyze both SMEs and large companies in this area, applying quantitative, qualitative and secondary data analysis techniques. Research deals with CSR in 
tourism firms, sustainable tourism, consumer trust, consumer perceptions and attitudes towards CSR practice in tourism firms (e.g. Kang et al., 2012; Marchoo et al., 2014).

$V$. Textile and clothing. In this industry researchers have studied issues such as supply chain management, sourcing (for example in China or Sri Lanka), ethical trade, worker treatment, homeworker status and conditions, women workers, sweatshops, union organizing, anticonsumerism. Most articles used case studies to analyze garment firms and their suppliers. Articles have appeared in a variety of journals such as Journal of Cultural Studies, Journal of Business Ethics, Global Networks - A Journal of Transnational Affairs and Progress in Development Studies (e.g. Ross, 2008; Burchielli et al., 2009).

VI. Food. Studies on CSR in the food industry focus on a variety of topics including CSR communication, organic products, consumer trust, ethical labels, nutrition facts, fair trade, slow food, social movements, transparency, information disclosure, consumer attitudes to food products and food companies. Most of the research uses case studies and investigates specific food companies. Research has appeared in a variety of outlets such as Journal of Agricultural and Environmental Ethics, Journal of Business Ethics, British Food Journal and European Review of Agricultural Economics (e.g. Maloni and Brown, 2006; Hartmann, 2011).

VII. Banking. Research reporting on business ethics and responsible business practices in the banking sector uses mainly quantitative techniques and secondary data content analyses, focusing on corporate websites and annual reports. The issues and topics researched include the relationship between CSR and financial performance, drivers of CSR adoption, customer perception of their bank's CSR performance, CSR and corporate identity, regulations and their violation, and consumer awareness of CSR practices. Research has appeared in several journals such as Organization Studies, Journal of Banking \& Finance, Journal of Business Ethics and Service Business (e.g. Bravo et al., 2012; Wu and Shen, 2013). 
Figure 2 provides a conceptual representation of industries, as informed by our literature review. This representation maps the industries on which at least five articles have been published, according to the types of issues that were investigated predominantly. We identified four axes that can be used to map the industries: human issues, environmental issues, business ethics, and image and brand-related issues. As the figure shows, some issues were found to be dominant in some industries whereas in other industries a combination of issues has been investigated. Thus, in agriculture, forestry and fishing environmental issues seem to be dominant, while in food and retail a combination of human, business ethics and image and brand-related issues are investigated. Pharmaceuticals, weapons and tobacco industries have mainly raised interest in human and business ethics-related issues. Textile industry is highly marked by human issues and by a combination of business ethics and image and brand-related issues. While both mining and quarrying and tourism show a tendency for environmental issues, mining and quarrying attracts investigations related to business ethics, while tourism is more oriented towards examining brand and image-related issues (see Figure 2).

\section{Insert Figure 2 about here}

We present a selection of articles with details of samples, methods, conceptual frameworks, key issues and key findings in Table 7.

We now discuss the key issues and methods that characterize specific industries, and these industries' approaches toward these issues. We also highlight the main research gaps that emerge from the data.

\section{Discussion}


The results of our research indicate that the distribution of CSR studies across different industries is highly unequal. The bulk of research concentrates on a few industries while many industries are under-researched. This demonstrates that industry-specific CSR research is incomplete. The results show that surprisingly few articles focus on CSR practices in specific industries, given the thousands of articles that comprise CSR research as a whole, and that industry-specific CSR research needs to expand considerably in the future. There is scope for future CSR studies in industries that are underrepresented in or absent from our sample, such as electricity provision, restaurants and the automotive industry. This kind of research is of utmost importance, because industry characteristics greatly influence CSR practices, as prior research has documented (Amato and Amato, 2007; 2012; O’Connor and Shumate, 2010; Beschorner et al., 2013a). This need is also supported by the large number of citations that articles in our sample have attracted, indicating the relevance of this segment of CSR research, for both academics and practitioners.

Our results indicate that research covers a wide variety of topics. We also highlight the prevalence of specific topics in specific industries. For example, research on the textile and clothing industry focuses mainly on labor-related issues (women workers, homeworkers, sweatshops) whereas studies on mining and quarrying deal with environmental issues and relations between mining companies and communities. In banking, the focus is on business ethics and on CSR reporting and brand building. This industry seems to pursue CSR largely for reputation-building purposes, and to consider business ethics and compliance as separate issues.

While the research issues clearly stem from the major concerns of each industry, an examination of the literature on different industries might identify other issues worthy of research. Thus, for example, the labor-related issues prevalent in the textile and clothing 
industry should perhaps also be examined in other sectors, such as mining, transportation, food, agriculture or forestry. A more systematic examination of various CSR-related issues across industries would identify how industry context shapes CSR practice, leading to a model of industry influence on CSR.

The various industries also address their CSR priorities in different ways, which reveal their different motivations for pursuing CSR. Our research found that most industries have moved beyond philanthropic inclinations. Bill Frederick described this early phase as $\mathrm{CSR}_{1}$. It entailed managing the business for profit first, and then donating to charitable causes out of a sense of moral duty to society (Frederick, 2006, p. 36). Especially in the extractive industries, companies now focus on pragmatic CSR methods and models (i.e. how CSR should be implemented), largely to manage risk. This is characteristic of what Frederick called $\mathrm{CSR}_{2}$, which emphasized the tools, techniques, organizational structures and behavioral systems a socially responsive company should use (Frederick, 2006, p. 43). For instance, we found this orientation in the energy industry, where environmental and safety risk demands strict compliance and efficient management models.

However, we also observed that companies in some industries are going yet further. The wide range of CSR research topics in the retail industry indicates a more sophisticated understanding of CSR. Our findings do not suggest that the retail industry's proximity to the customer leads to research focusing on philanthropic activities, as O'Connor and Shumate (2010) suggested. Instead, proximity to the customer seems to stimulate interest in how commitment to brand principles and ethical trade can enhance brand value, trust, and customer loyalty. We see here that researchers are interested in studying integrated CSR, which would be characteristic of Frederick's (2006) $\mathrm{CSR}_{3}$. This entails integrating CSR fully into corporate business models and, in so doing, reconciling business and moral imperatives. 
The shift to $\mathrm{CSR}_{3}$ is indeed reflected in our findings. From our perspective, papers combine concerns for moral correctness and for proper policies and programs. In the pharmaceutical industry, for instance, we see great interest in the stakeholder approach to CSR, in addition to the more typical concern for legality. The stakeholder approach is also characteristic of the mining industry. One question in this regard is whether the stakeholder approach has a sufficiently strong normative basis. In their most recent reflection on the development of stakeholder theory, Freeman et al. (2010) address, with varying success, the accusation that the theory is normatively vacuous. More research on the normative dimension of industryspecific CSR would be helpful in this regard.

Concerning the methodologies used in various industries, some interesting facts emerged. For instance, CSR studies in the mining industry are predominantly qualitative. There certainly seems to be a need for more quantitative studies in this industry. The fact that studies in the tourism industry span both SMEs and large companies may explain the variety of methods employed, however, it would be good to see research on CSR in SMEs in other industries as well. Though it is not surprising that CSR research in the textile industry largely focuses on supply chain issues, one would hope that the dominant case study methodology will be supplemented with quantitative research and other qualitative research methods. For example, since studying normative orientations in this industry seems particularly important, abductive methods (Alvesson and Skoldberg, 2009) may be of particular interest.

Furthermore, our results also suggest that a more thorough and systematic examination of CSR practices in different industries might lead to the development of new conceptual frameworks that would enhance understanding of specific issues in specific industries. Indeed, while the articles examined use many different frameworks, most of them are used independently, and not combined with other frameworks. Combining frameworks from different disciplines, and developing original conceptual models would allow to further 
advance this field of study. Future research should also strive to integrate contextual (industry-specific) features in both theoretical and empirical studies.

\section{Conclusion}

The key contribution of our work is that we provide the first extensive, systematic analysis of the industry-specific CSR literature. We map this field of study, highlight the trends, and point to the approaches that the most researched industries take towards CSR. In the process, we identify gaps and suggest avenues for future research. However, as with any study, this one has limitations.

Methodologically speaking, one of the main limitations is that the study is restricted to journal articles. Many books have been published on CSR, including that by Beschorner et al. (2013a), which focused on sector-specific corporate responsibility, it will be important to consider such work in future analyses. Moreover, studies of particular journals or topics could lead to more detailed analyses and discussion of contextual variables.

Much needs to be done to develop the content and theoretical contributions of this research field. Our study opens up many new research questions and perspectives. For example, more research is necessary to understand how far CSR in specific industries has come in bridging the gap between normative concerns and pragmatic management tools. For instance, it would be interesting to see whether research addresses the terms "CSR" and "Business Ethics" together, or separately. This may show whether normative concerns are fully integrated into studies of CSR policies and management or into articles that pursue "the business case for CSR". Studying differences in approach in certain geographical contexts would also be interesting - could it be that studies of the European context focus more on CSR, and those originating from the USA more on business ethics, corporate governance and compliance? 
In addition to pointing to new research directions, our study has implications for practitioners and policy makers. It indicates to managers the extent to which CSR-related issues have been scrutinized and are considered important in different industries, and how the industry-specific context influences CSR focus. Our analysis also shows that policy makers need to understand the influence of context on CSR better. Such an understanding would enable them to develop policies accounting for the specific feature of different industrial contexts, rather than merely “one size fits all” measures.

\section{References}

Aguinis, H. (2011), “Organizational responsibility: Doing good and doing well”, in Zedeck, S. (Ed.), APA handbook of industrial and organizational psychology, Vol. 3, American Psychological Association, Washington, DC, pp. 855-879.

Aguinis, H. and Glavas, A. (2012), “What we know and don't know about Corporate Social Responsibility: A review and research agenda", Journal of Management, Vol. 38, No. 4, pp. 932-968.

Alvesson, M. and Sköldberg, K. (2009), Reflexive methodology: New vistas for qualitative research, Sage, London.

Amato, L.H. and Amato, C.H. (2007), "The effects of firm size and industry on corporate giving”, Journal of Business Ethics, Vol. 72, No. 3, pp. 229-241.

Amato, L.H. and Amato, C.H. (2012), "Retail philanthropy: Firm size, industry and business cycle", Journal of Business Ethics, Vol. 107, No. 4, pp. 435-448.

Amidi, M. and Bienstock, C.C. (2014), "Corporate Sustainability: an integrative definition and framework to evaluate corporate and guide academic research", Journal of Cleaner Production, Vol. 76, No. 1, pp. 12-19. 
Barney, J. (1991), "Firm resources and sustained competitive advantage", Journal of Management, Vol. 17, No. 1, pp. 99-120.

Beschorner, T., Hajduk, T. and Simeonov, S. (Eds.) (2013a), Corporate Responsibility in Europe, Verlag Bertelsmann Stiftung, Gütersloh.

Beschorner, T., Hajduk, T. and Simeonov, S. (2013b), "Sector-specific Corporate Responsibility in Europe: Introduction", in Beschorner, T., Hajduk, T. and Simeonov, S. (Eds.), Corporate Responsibility in Europe, Verlag Bertelsmann Stiftung, Gütersloh, pp. 2339.

Brammer, S. and Millington, A. (2005), “Corporate reputation and philanthropy: An empirical analysis", Journal of Business Ethics, Vol. 61, No. 1, pp. 29-44.

Bravo, R., Matute, J. and Pina, J.M. (2012), “Corporate Social Responsibility as a vehicle to reveal the corporate identity: A study focused on the websites of Spanish financial entities", Journal of Business Ethics, Vol. 107, No. 2, pp. 129-146.

Bruyaka, O., Zeitzmann, H.K., Chalamon, I., Wokutch, R.E. and Thakur, P. (2013), "Strategic Corporate Social Responsibility and orphan drug development: insights from the US and the EU biopharmaceutical industry", Journal of Business Ethics, Vol. 117, No. 1, pp. 45-65.

Burcielli, R., Deloney, A., Tate, J. and Coventry, K. (2009), “The FairWear campaign: An ethical network in the Australian garment industry", Journal of Business Ethics, Vol. 90 (Special issue), pp. 575-588.

Campbell, J.L. (2007), "Why would corporations behave in socially responsible ways? An institutional theory of corporate social responsibility", Academy of Management Review, Vol. 32, No. 3, pp. 946-967.

Carroll, A.B. (1979), "A three-dimensional conceptual model of corporate performance", Academy of Management Review, Vol. 4, No.4, pp. 497-505. 
Carroll, A.B. (1991), “The pyramid of corporate social responsibility: Toward the moral management of organizational stakeholders”, Business Horizons, Vol. 34, No. 4, pp. 39-48.

Carroll, A.B. (1999), “Corporate Social Responsibility. Evolution of a definitional construct”, Business \& Society, Vol. 38, No. 3, pp. 268-295.

Carroll, A.B. and Shabana, K.M. (2010), "The business case for corporate social responsibility: a review of concepts, research and practice", International Journal of Management Reviews, Vol. 12, No. 1, pp. 85-105.

Claydon, J. (2011), “A new direction for CSR: the shortcomings of previous CSR models and the rationale for a new model”, Social Responsibility Journal, Vol. 7, No. 3, pp. 405-420.

Cragg, W. and Greenbaum, A. (2002), "Reasoning about responsibilities: Mining company managers on what stakeholders are owed", Journal of Business Ethics, Vol. 39, No. 3, pp. 319-335.

Dabic, M., Gonzales-Loureiro, M. and Furrer, O. (2014), "Research on the strategy of multinational enterprises: Key approaches and new avenues”, Business Research Quarterly, Vol. 17, No. 2, pp. 129-148.

European Commission (2011), A renewed EU strategy 2011-14 for Corporate Social Responsibility, European Commission, Brussels.

Fairbrass, J. (2011), "Exploring Corporate Social Responsibility policy in the European Union: A discursive institutionalist analysis”, Journal of Common Market Studies, Vol. 49, No. 5, pp. 949-970.

Fairbrass, J. and Zueva-Owens, A. (2012), “Conceptualising Corporate Social Responsibility: 'Relational governance' assessed, augmented, and adapted”, Journal of Business Ethics, Vol. 105, No. 3, pp. 321-335. 
Flanagan, W. and Whiteman, G. (2007), “AIDS is not a business: A study in global corporate responsibility - Securing access to low-cost HIV medications", Journal of Business Ethics, Vol. 73, No. 1, pp. 65-75.

Frederick, W.C. (1994), "From CSR1 to CSR2. The maturing of business-and-society thought”, Business \& Society, Vol. 33, No. 2, pp. 150-164.

Frederick, W.C. (2006), Corporation, be good? The story of Corporate Social Responsibility, Dog Ear Publishing, Indianapolis.

Freeman, R.E. (1984), Strategic management: A stakeholder approach, Pitman Publishing, London.

Freeman, R.E. (1994), “The politics of stakeholder theory: Some future directions”, Business Ethics Quarterly, Vol. 4, No. 4, pp. 409-421.

Freeman, R.E. Harrison, J.S., Wicks, A.C. Parmar, B.L. and de Colle, S. (2010), Stakeholder Theory: The state of the art, Cambridge University Press, Cambridge.

Friedman, M. (1962), Capitalism and freedom, Chicago University Press, Chicago.

Friedman, M. (1970), “The Social Responsibility of business is to increase profits”, The New York Times Magazine, September 13.

Gray, D., Roos, G. and Rastas, T. (2004), "What intangible resources do companies value, measure, and report? A synthesis of UK and Finnish research", International Journal of Learning and Intellectual Capital, Vol. 1, No. 3, pp. 242-261.

Hah, K. and Freeman, S. (2014), "Multinational enterprise subsidiaries and their CSR: A conceptual framework of the management of CSR in smaller emerging economies", Journal of Business Ethics, Vol. 122, No. 1, pp. 125-136.

Hartmann, M. (2011), “Corporate social responsibility in the food sector”, European Review of Agricultural Economics, Vol. 38, No. 3, pp. 297-324. 
Hemphill, T.A. (2010), "Extraordinary pricing of orphan drugs: Is it a socially responsible strategy for the US pharmaceutical industry?”, Journal of Business Ethics, Vol. 94, No. 2, pp. 225-242.

Hendry, J.R. (2006), "Taking aim at business: What factors lead environmental nongovernmental organizations to target particular firms?”, Business \& Society, Vol. 45, No. 1, pp. $47-86$.

Holder-Webb, L., Cohen, J.R., Nath, L. and Wood, D. (2008), “The supply of Corporate Social Responsibility disclosures among U.S. firms", Journal of Business Ethics, Vol. 84, No. 4, pp. 497-527.

Hughes, A. (2005), "Corporate strategy and the management of ethical trade: The case of the UK food and clothing retailers", Environment and Planning A, Vol. 37, No. 7, pp. 1145-1163. Hughes, A., McEwan, C. and Bek, D. (2013), "Retailers, supply networks and changing articulations of ethicality: lessons from Flower Valley in South Africa", Journal of Economic Geography, Vol. 13, No. 2, pp. 1468-2702.

Isaksson, L., Kessling, T. and Harvey, M. (2014), “Corporate Social Responsibly: Who cares?”, Organizational Dynamics, Vol. 43, No. 1, pp. 76-84.

Jones, P., Comfort, D., Hillier, D. and Eastwood, I. (2005), “Corporate social responsibility: A case study of the UK's leading food retailers", British Food Journal, Vol. 107, No. 6, pp. $423-435$.

Kang, K.H., Stein, L., Heo, C.Y. and Lee, S. (2012), “Consumers' willingness to pay for green initiatives of the hotel industry", International Journal of Hospitality Management, Vol. 31, No. 2, pp. 564-572.

Lamberti, L. and Lettieri, E. (2009), "CSR practices and corporate strategy: Evidence from a longitudinal case study", Journal of Business Ethics, Vol. 87, No. 2, pp. 153-168. 
Laplume, A.O., Sonpar, K., and Litz, R.A. (2008), "Stakeholder theory: Reviewing a theory that moves us", Journal of Management, Vol. 34, No. 6, pp. 1152-1189.

Lee, M.D.P. (2008), “A review of the theories of corporate social responsibility: Its evolutionary path and the road ahead", International Journal of Management Reviews, Vol. 10, No. 1, pp. 53-73.

Levy, O. (2005), "The influence of top management team attention patterns on global strategic posture of firms", Journal of Organizational Behavior, Vol. 26, No. 7, pp. 797-819. Logsdon, J.M. and Wood, D.J. (2005), “Global business citizenship and voluntary codes of ethical conduct”, Journal of Business Ethics, Vol. 59, No. 1, pp. 55-67.

Maloni, M.J. and Brown, M.E. (2006), “Corporate Social Responsibility in the supply chain: An application in the food industry", Journal of Business Ethics, Vol. 68, No. 1, pp. 35-52.

Marchoo, W., Butcher, K. and Watkins, M. (2014), “Tour booking: Do travelers respond to tourism accreditation and codes of ethics initiatives", Journal of Travel \& Tourism Marketing, Vol. 31, No. 1, pp. 16-36.

McWilliams, A. and Siegel, D. (2001), “Corporate social responsibility: A theory of the firm perspective", Academy of Management Review, Vol. 26, No. 1, pp. 117-127.

McWilliams, A., Siegel, D.S. and Wright, P.M. (2006), "Corporate social responsibility: Strategic implications”, Journal of Management Studies, Vol. 43, No. 1, pp. 1-18.

Mikkila, M., Kolehmainen, O. and Pukkala, T. (2005), "Multi-attribute assessment of acceptability of operations in the pulp and paper industries", Forest Policy and Economics, Vol. 7, No. 2, pp. 227-243.

Mir, M.Z. and Rahaman, A. (2011), “In pursuit of environmental excellence. A stakeholder analysis of the environmental management strategies and performance of an Australian energy company", Accounting, Auditing \& Accountability Journal, Vol. 24, No. 7, pp. 848878. 
Montiel, I. and Delgado-Ceballos, J. (2014), "Defining and Measuring Corporate Sustainability: Are we there yet?", Organization \& Environment, Vol. 27, No. 2, pp. 113139.

Morris, R. (1994), “Computerized content analysis in management research: A demonstration of advantages \& limitations", Journal of Management, Vol. 20, No. 4, pp. 903-931.

North, D.C. (1990), Institutions, institutional change and economic performance, Norton, New York.

O’Connor, A. and Shumate, M. (2010), “An economic industry and institutional level of analysis of Corporate Social Responsibility communication”, Management Communication Quarterly, Vol. 24, No. 4, pp. 529-551.

Painter-Morland, M. and ten Bos, R. (Eds.) (2011). Business ethics and continental philosophy, Cambridge University Press, Cambridge, UK.

Pollach, I. (2011), "Software review: Wordstat 5.0”, Organizational Research Methods, Vol. 14, No. 4, pp. 741-744.

Porter, M.E. and Kramer, M.R. (2006), "Strategy \& society: The link between competitive advantage and corporate social responsibility", Harvard Business Review, Vol. 84, No. 12, pp. 78-92.

Roberts, R.W. (1992), "Determinants of corporate social responsibility disclosure: An application of stakeholder theory", Accounting, Organizations and Society, Vol. 17, No. 6, pp. $595-612$.

Ross, A. (2008), "The quandaries of consumer-based activism: A low-wage case study", Cultural Studies, Vol. 22, No. 5, pp. 770-787.

Rowley, T. and Berman, S. (2000), "A brand new brand of corporate social performance", Business \& Society, Vol. 39, No. 4, pp. 397-418. 
Sacconi, L. (2011), "A Rawlsian view of CSR and game theory (part 1)", in Sacconi, L., Blair, M., Freeman, R. and Vercelli, A. (Eds.). Corporate social responsibility and corporate governance: The contribution of economic theory and related disciplines, Palgrave Macmillan, London, pp. 157-193.

Salzmann, O., Ionescu-Somers, A. and Steger, U. (2005), “The business case for corporate sustainability: literature review and research options", European Management Journal, Vol. 23, No. 1, pp. 27-36.

Schwartz, M.S. and Carroll, A.B. (2003), "Corporate social responsibility: A three-domain approach”, Business Ethics Quarterly, Vol. 13, No. 4, pp. 503-530.

Scott, W.R. (1995), Institutions and organizations, Sage, Thousand Oaks, CA.

Sharma, S. and Henriques, I. (2005), "Stakeholder influences on sustainability practices in the Canadian forest products industry", Strategic Management Journal, Vol. 26, No. 2, pp. 159180.

Stevens, J.M., Steensma, H.K., Harrison, D.A. and Cochran, P.L. (2005), "Symbolic or substantive document? The influence of ethics codes on financial executives' decisions", Strategic Management Journal, Vol. 26, No. 2, pp. 181-195.

ten Bos, R. and Dunne, S. (2011), "Corporate social responsibility”, in Painter-Morland, M. and ten Bos, R. (Eds.). Business ethics and continental philosophy, Cambridge University Press, Cambridge, UK, pp. 242-262.

Torugsa, N.A., O'Donohue, W. and Hecker, R. (2013), "Proactive CSR: An empirical analysis of the role of its economic, social and environmental dimensions on the association between capability and performance", Journal of Business Ethics, Vol. 115, No. 2, pp. 383402.

Useem, M. (1988), "Market and institutional factors in corporate contributions" California Management Review, Vol. 30, No. 2, pp. 77-88. 
Wang, L. and Juslin, H. (2013), “Corporate Social Responsibility in the Chinese forest industry: Understanding multiple stakeholder perceptions", Corporate Social Responsibility and Environmental Management, Vol. 20, No. 3, pp. 129-145.

Wernerfelt, B. (1984), “A resource-based view of the firm”, Strategic Management Journal, Vol. 5, No. 2, pp. 171-180.

Wood, D.J. (1991), “Corporate social performance revisited”, Academy of Management Review, Vol. 16, No. 4, pp. 691-718.

Wu, M.-W. and Shen, C.-H. (2013), “Corporate social responsibility in the banking industry: Motives and financial performance", Journal of Banking \& Finance, Vol. 37, No. 9, pp. 3229-3547.

Yakovleva, N. and Vazquez-Brust, D. (2012), "Stakeholder perspectives on CSR of mining MNCs in Argentina”, Journal of Business Ethics, Vol. 102, No. 2, pp. 191-211. 
Figure 1. Number of articles published by year, 1995-2014.

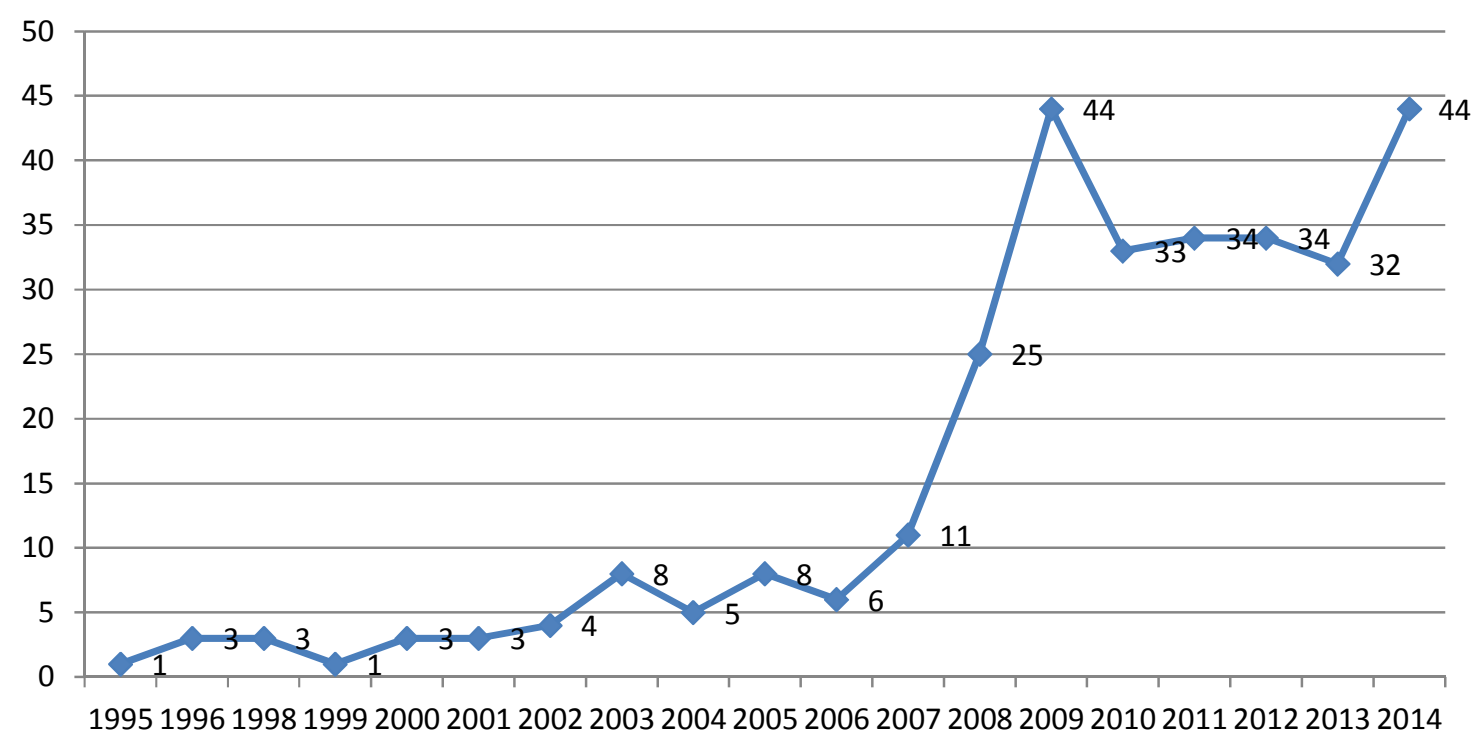

Source: Authors, based on SSCI Web of Science. 
1

2

3

4

5

6

7

8

9

10

11

12

13

14

15

16

17

18

19

20

21

22

23

24

25

26

27

28

29

30

31

32

33

34

35

36

37

38

39

40

41

42

43

44

45

46

47

48

49

50

51

52

53

54

55

56

57

58

59

60

Figure 2. Mapping of industries based on CSR-related issues studied

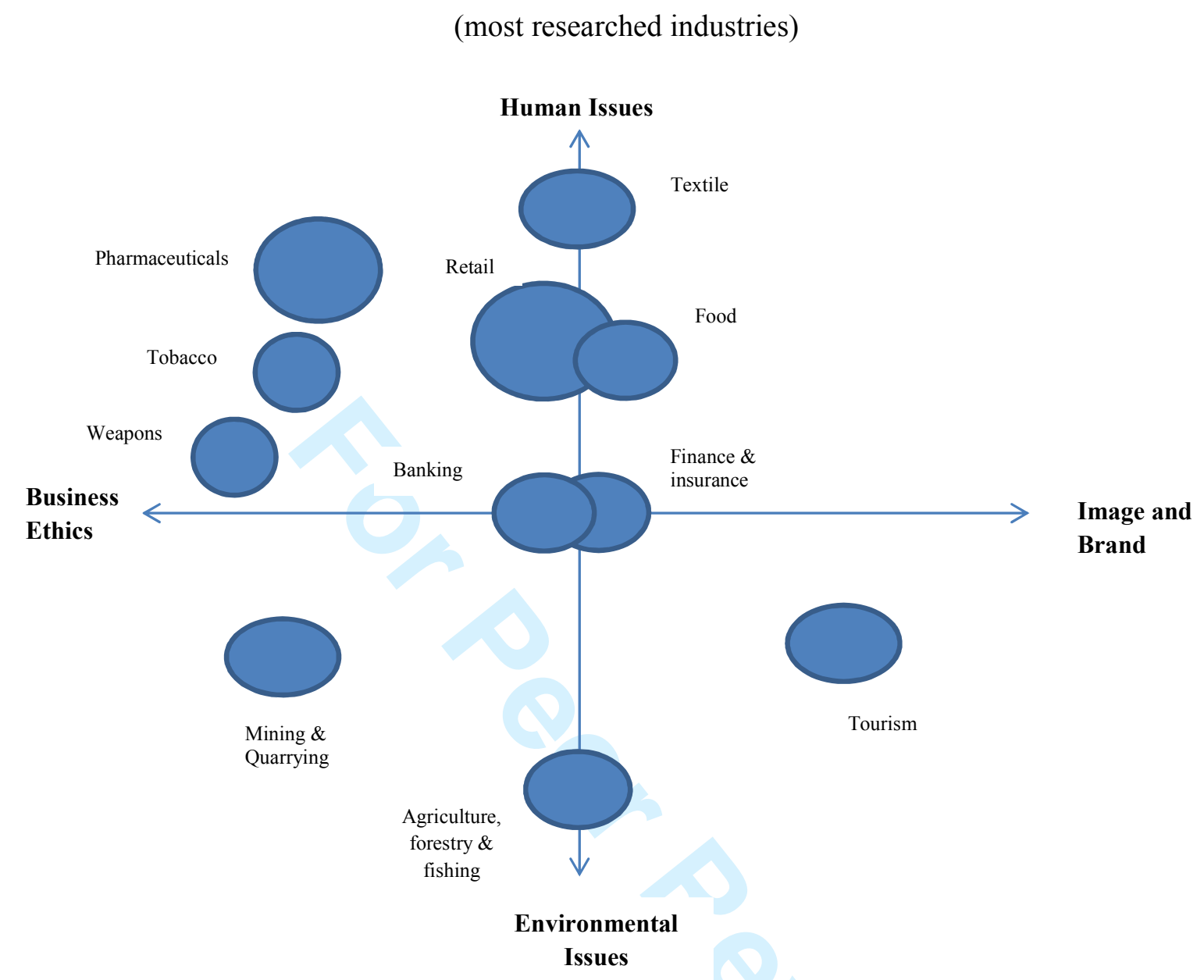

Source: Authors, based on SSCI Web of Science.

Note: The size of the bubbles corresponds to the number of published articles. 
Table 1. Characteristics of the sample

\begin{tabular}{|l|c|}
\hline Number of results & 302 \\
\hline Number of citations (excluding self-citation) & 3352 \\
\hline Average number of citations per item & 11.10 \\
\hline h index & 30 \\
\hline
\end{tabular}

Source: Authors, based on SSCI Web of Science. 
Table 2. Distribution of articles by journal (Top 10 journals)

\begin{tabular}{|l|c|c|c|}
\hline Journal & $\begin{array}{c}\text { No. of } \\
\text { articles }\end{array}$ & $\begin{array}{c}\text { Frequency } \\
\mathbf{( \% )}\end{array}$ & $\begin{array}{c}\text { Cumulative } \\
\text { frequency } \\
\text { (\%) }\end{array}$ \\
\hline Journal of Business Ethics & 112 & 37,09 & 37,09 \\
\hline $\begin{array}{l}\text { Corporate Social Responsibility and } \\
\text { Environmental Management }\end{array}$ & 7 & 2,32 & 39,41 \\
\hline Business Ethics : A European Review & 7 & 2,32 & 41,73 \\
\hline Management Decision & 5 & 1,66 & 43,39 \\
\hline Journal of Economic Geography & 5 & 1,66 & 45,05 \\
\hline Business Strategy and the Environment & 5 & 1,66 & 46,71 \\
\hline Journal of Cleaner Production & 4 & 1,32 & 48,03 \\
\hline $\begin{array}{l}\text { International Journal of Hospitality } \\
\text { Management }\end{array}$ & 4 & 1,32 & 49,35 \\
\hline Business \& Society & 4 & 1,32 & 50,67 \\
\hline British Food Journal & 4 & 1,32 & 51,99 \\
\hline
\end{tabular}

Source: Authors, based on SSCI Web of Science. 
Table 3. Distribution of Articles by Authors' Country-of-Origin (Top 10 countries)

\begin{tabular}{|l|c|c|c|}
\hline Country & $\begin{array}{c}\text { No. of } \\
\text { Articles }\end{array}$ & $\begin{array}{c}\text { Frequency } \\
\mathbf{( \% )}\end{array}$ & $\begin{array}{c}\text { Cumulative } \\
\text { frequency } \\
(\mathbf{\%})\end{array}$ \\
\hline USA & 73 & 24,17 & 24,17 \\
\hline England & 61 & 20,20 & 44,37 \\
\hline Australia & 27 & 8,94 & 53,31 \\
\hline Spain & 26 & 8,61 & 61,92 \\
\hline Canada & 19 & 6,29 & 68,21 \\
\hline China & 12 & 3,97 & 72,19 \\
\hline Netherlands & 12 & 3,97 & 76,16 \\
\hline Finland & 11 & 3,64 & 79,80 \\
\hline Taiwan & 10 & 3,31 & 83,11 \\
\hline France & 10 & 3,31 & 86,42 \\
\hline Sourc: Auth
\end{tabular}

Source: Authors, based on SSCI Web of Science. 
Table 4. Distribution of authors' keywords (Top 30 keywords)

\begin{tabular}{|c|c|c|c|}
\hline Authors' keywords & Nb. of papers & $\begin{array}{c}\text { Distribution of total } \\
882 \text { used keywords } \\
(\%)\end{array}$ & $\begin{array}{c}\text { Distribution of } \\
\text { keywords in the } 302 \\
\text { papers }(\%)\end{array}$ \\
\hline $\begin{array}{l}\text { Corporate social } \\
\text { responsibility }\end{array}$ & 127 & 14.40 & 42,05 \\
\hline Business ethics & 27 & 3.06 & 8,94 \\
\hline Ethics & 24 & 2.72 & 7,95 \\
\hline CSR & 14 & 1.59 & 4,64 \\
\hline China & 11 & 1.25 & 3,64 \\
\hline Social responsibility & 10 & 1.13 & 3,31 \\
\hline Sustainability & 9 & 1.02 & 2,98 \\
\hline $\begin{array}{l}\text { Corporate Social } \\
\text { Responsibility (CSR) }\end{array}$ & 9 & 1.02 & 2,98 \\
\hline Stakeholders & 8 & 0.91 & 2,65 \\
\hline $\begin{array}{l}\text { Sustainable } \\
\text { development }\end{array}$ & 7 & 0.79 & 2,32 \\
\hline Content analysis & 7 & 0.79 & 2,32 \\
\hline $\begin{array}{l}\text { Supply chain } \\
\text { management }\end{array}$ & 7 & 0.79 & 2,32 \\
\hline $\begin{array}{l}\text { Corporate } \\
\text { governance }\end{array}$ & 7 & 0.79 & 2,32 \\
\hline Globalization & 6 & 0.68 & 1,99 \\
\hline Governance & 6 & 0.68 & 1,99 \\
\hline $\begin{array}{l}\text { Corporate } \\
\text { responsibility }\end{array}$ & 6 & 0.68 & 1,99 \\
\hline $\begin{array}{l}\text { Stakeholder } \\
\text { engagement }\end{array}$ & 6 & 0.68 & 1,99 \\
\hline Institutional theory & 6 & 0.68 & 1,99 \\
\hline Codes of conduct & 5 & 0.57 & 1,66 \\
\hline $\begin{array}{l}\text { Financial } \\
\text { performance }\end{array}$ & 5 & 0.57 & 1,66 \\
\hline Ethical trade & 5 & 0.57 & 1,66 \\
\hline Stakeholder theory & 5 & 0.57 & 1,66 \\
\hline Human rights & 4 & 0.45 & 1,32 \\
\hline Global value chains & 4 & 0.45 & 1,32 \\
\hline Food industry & 4 & 0.5 & 1,32 \\
\hline United Kingdom & 4 & 0.45 & 1,32 \\
\hline Corporate citizenship & 4 & 0.45 & 1,32 \\
\hline Consumer & 4 & 0.45 & 1,32 \\
\hline Codes of ethics & 4 & 0.45 & 1,32 \\
\hline Internet & 3 & 0.34 & 0,99 \\
\hline
\end{tabular}

Source: Authors, based on SSCI Web of Science. 
Table 5. Distribution of papers according to the sector

\begin{tabular}{|l|c|c|}
\hline Sector & Nb. of papers & Frequency (\%) \\
\hline Primary & 18 & 5,96 \\
\hline Secondary & 71 & 23,51 \\
\hline Tertiary & 73 & 24,17 \\
\hline Cross-sector and sector not specified & 140 & 46,35 \\
\hline
\end{tabular}

Source: Authors, based on SSCI Web of Science. 
Table 6. Industries which have been reported on in relation to CSR practices

\begin{tabular}{|c|c|c|}
\hline Industry & $\begin{array}{l}\text { Nb. of } \\
\text { papers }\end{array}$ & $\begin{array}{l}\text { Frequency } \\
(\%)\end{array}$ \\
\hline Retail sale & 15 & 4,97 \\
\hline Pharmaceuticals (manufacture of pharmaceuticals) & 11 & 3,64 \\
\hline $\begin{array}{l}\text { Mining and quarrying (extraction of coal, metals, } \\
\text { petroleum, gas, peat, salt, sand etc.) }\end{array}$ & 9 & 2,98 \\
\hline Tourism and hospitality (short term accommodation) & 9 & 2,98 \\
\hline Textile and clothing (manufacture of wearing apparel) & 9 & 2,98 \\
\hline Food (manufacture of food products) & 8 & 2,65 \\
\hline Banking (monetary intermediation) & 8 & 2,65 \\
\hline Financial and insurance activities & 7 & 2,32 \\
\hline Agriculture, forestry and fishing & 6 & 1,99 \\
\hline Tobacco (manufacture of tobacco products) & 5 & 1,66 \\
\hline $\begin{array}{l}\text { Weapons and ammunition (manufacture of weapons and } \\
\text { ammunition) }\end{array}$ & 5 & 1,66 \\
\hline $\begin{array}{l}\text { Information and communication (social networks, media, } \\
\text { ICT) }\end{array}$ & 4 & 1,32 \\
\hline Automotive (manufacture of motor vehicles) & 4 & 1,32 \\
\hline Sports goods (manufacture of sports goods) & 4 & 1,32 \\
\hline Restaurants and mobile food service activities & 4 & 1,32 \\
\hline Telecommunications & 4 & 1,32 \\
\hline Electric power generation, transmission and distribution & 3 & 0,99 \\
\hline Gambling and betting activities & 3 & 0,99 \\
\hline Activities of sports clubs & 2 & 0,66 \\
\hline Advertising & 2 & 0,66 \\
\hline Education & 2 & 0,66 \\
\hline Furniture (manufacture of furniture) & 2 & 0,66 \\
\hline $\begin{array}{l}\text { Machinery and equipment (manufacture of machinery and } \\
\text { equipment) }\end{array}$ & 2 & 0,66 \\
\hline $\begin{array}{l}\text { Paper and paper products (manufacture of paper and paper } \\
\text { products) }\end{array}$ & 2 & 0,66 \\
\hline Sea and coastal water transport & 2 & 0,66 \\
\hline Various industries and other & 170 & 56,29 \\
\hline
\end{tabular}

Source: Authors, based on SSCI Web of Science. 
Table 7. Selection of articles reporting on CSR activities in different industries/sectors

\begin{tabular}{|c|c|c|c|c|c|c|}
\hline Author(s) & $\begin{array}{c}\text { Industry/ } \\
\text { sector }\end{array}$ & $\begin{array}{l}\text { Conceptual } \\
\text { framework }\end{array}$ & Method & Sample & Key issues studied & Main findings \\
\hline $\begin{array}{l}\text { Cragg and } \\
\text { Greenbaum } \\
(2002)\end{array}$ & Mining & $\begin{array}{l}\text { Stakeholder } \\
\text { theory }\end{array}$ & $\begin{array}{l}\text { Qualitative case } \\
\text { study }\end{array}$ & $\begin{array}{l}\text { One mining } \\
\text { company }\end{array}$ & $\begin{array}{l}\text { How managers talk about } \\
\text { CSR and which explicit and } \\
\text { implicit value systems and } \\
\text { moral logics inform this talk }\end{array}$ & $\begin{array}{l}\text { Confirmation that stakeholder theory is } \\
\text { grounded in the realities of management practice } \\
\text { and behavior. }\end{array}$ \\
\hline $\begin{array}{l}\text { Jones et al. } \\
(2005)\end{array}$ & Retail & Reporting & $\begin{array}{l}\text { Secondary data } \\
\text { analysis (annual } \\
\text { reports) }\end{array}$ & $\begin{array}{l}10 \text { leading UK } \\
\text { retailers }\end{array}$ & $\begin{array}{l}\text { Which CSR issues are } \\
\text { addressed and reported by } \\
\text { the UK's leading retailers }\end{array}$ & $\begin{array}{l}\text { Each of the leading food retailers has its own } \\
\text { approach to CSR. There are substantial } \\
\text { variations in the nature and extent of the } \\
\text { reporting process with some common ground in } \\
\text { reporting on a range of environmental issues, on } \\
\text { sourcing, on employees, on customers and on } \\
\text { the communities in which the retailers operate. }\end{array}$ \\
\hline $\begin{array}{l}\text { Mikkila et al. } \\
(2005)\end{array}$ & Pulp and paper & $\begin{array}{l}\text { Stakeholder } \\
\text { theory }\end{array}$ & Case studies & $\begin{array}{l}4 \text { case studies in } \\
4 \text { countries: } \\
\text { China, Finland, } \\
\text { Germany and } \\
\text { Portugal }\end{array}$ & $\begin{array}{l}\text { Corporate social } \\
\text { performance studied by } \\
\text { testing a potential indicator, } \\
\text { the acceptability of } \\
\text { operations. }\end{array}$ & $\begin{array}{l}\text { The concept of the acceptability of operations } \\
\text { varies from place to place. }\end{array}$ \\
\hline $\begin{array}{l}\text { Logsdon and } \\
\text { Wood (2005) }\end{array}$ & Petroleum & $\begin{array}{l}\text { Theory of } \\
\text { Global Business } \\
\text { Citizenship }\end{array}$ & Case studies & $\begin{array}{l}6 \text { global } \\
\text { companies }\end{array}$ & $\begin{array}{l}\text { Analysis of the codes of } \\
\text { business conduct from the } \\
\text { global perspective of } \\
\text { business citizenship theory. }\end{array}$ & $\begin{array}{l}\text { Illustrations of the concepts of the theory of } \\
\text { Global Business Citizenship }\end{array}$ \\
\hline $\begin{array}{l}\text { Hughes } \\
(2005)\end{array}$ & Retail & $\begin{array}{l}\text { Corporate } \\
\text { strategy and } \\
\text { inter-firm } \\
\text { organization }\end{array}$ & & $\begin{array}{l}\text { UK food and } \\
\text { clothing } \\
\text { retailers }\end{array}$ & Ethical trading principles & $\begin{array}{l}\text { Suggests three contrasting modes of } \\
\text { organization for ethical monitoring are used by } \\
\text { retail companies: the arm's-length approach, the } \\
\text { coordinated approach, and the developmental } \\
\text { approach, each of which has contrasting } \\
\text { implications for suppliers and workers at } \\
\text { production sites. }\end{array}$ \\
\hline
\end{tabular}


Table 7. Selection of articles reporting on CSR activities in different industries/sectors (continued)

\begin{tabular}{|c|c|c|c|c|c|c|}
\hline Author(s) & $\begin{array}{l}\text { Industry/ } \\
\text { sector }\end{array}$ & $\begin{array}{l}\text { Conceptual } \\
\text { framework }\end{array}$ & Method & Sample & Key issues studied & Main findings \\
\hline $\begin{array}{l}\text { Mir and } \\
\text { Rahaman } \\
(2011)\end{array}$ & Energy & $\begin{array}{l}\text { Stakeholder } \\
\text { theory }\end{array}$ & Case study & $\begin{array}{l}1 \text { Australian } \\
\text { energy company }\end{array}$ & $\begin{array}{l}\text { How environmental } \\
\text { concerns are handled and } \\
\text { what outcomes are achieved } \\
\text { in terms of environmental } \\
\text { and economic performance }\end{array}$ & $\begin{array}{l}\text { There are socio-political processes that are } \\
\text { enlisted to control, monitor, and instill discipline } \\
\text { in the organization's pursuit of its social } \\
\text { initiatives, which help to improve both its } \\
\text { financial and environmental performance. }\end{array}$ \\
\hline $\begin{array}{l}\text { Torugsa et al. } \\
(2013)\end{array}$ & $\begin{array}{l}\text { Machinery and } \\
\text { equipment }\end{array}$ & $\begin{array}{l}\text { Resource- } \\
\text { based view } \\
(\mathrm{RBV})\end{array}$ & $\begin{array}{l}\text { Quantitative } \\
\text { survey }\end{array}$ & $\begin{array}{l}\text { 171 SMEs in } \\
\text { Australia }\end{array}$ & $\begin{array}{l}\text { The association between } \\
\text { three specified capabilities } \\
\text { (shared vision, stakeholder } \\
\text { management and strategic } \\
\text { proactivity), proactive CSR } \\
\text { and financial performance. }\end{array}$ & $\begin{array}{l}\text { All specified capabilities are positively } \\
\text { associated with adoption of proactive CSR by } \\
\text { SMEs. Proactive CSR is associated with an } \\
\text { improvement in firm financial performance. } \\
\text { Proactive CSR mediates the association between } \\
\text { capabilities and financial performance. }\end{array}$ \\
\hline $\begin{array}{l}\text { Wang and } \\
\text { Juslin (2013) }\end{array}$ & Forest industry & $\begin{array}{l}\text { Stakeholder } \\
\text { theory }\end{array}$ & Quantitative & $\begin{array}{l}810 \\
\text { observations }\end{array}$ & $\begin{array}{l}\text { Assessment of the CSR } \\
\text { performance of the Chinese } \\
\text { forest industry }\end{array}$ & $\begin{array}{l}\text { Stakeholder theory is a useful tool for collecting } \\
\text { and evaluating CSR data. Chinese forest } \\
\text { industry performs slightly better in its economic } \\
\text { responsibility than environmental and social } \\
\text { responsibilities. Values have a significant effect } \\
\text { on the stakeholder perception of CSR } \\
\text { performance. }\end{array}$ \\
\hline $\begin{array}{l}\text { Wu and Shen } \\
(2013)\end{array}$ & Banking & $\begin{array}{l}\text { Link between } \\
\text { CSR and } \\
\text { Financial } \\
\text { Performance }\end{array}$ & Quantitative & $\begin{array}{l}162 \text { banks in } 22 \\
\text { countries }\end{array}$ & $\begin{array}{l}\text { Association between } \\
\text { corporate social } \\
\text { responsibility (CSR) and } \\
\text { financial performance (FP), } \\
\text { and driving motives of banks } \\
\text { to engage in CSR. }\end{array}$ & $\begin{array}{l}\text { CSR associates positively with FP in terms of } \\
\text { return on assets, return on equity, net interest } \\
\text { income, and non-interest income. In contrast, } \\
\text { CSR negatively associates with non-performing } \\
\text { loans. Hence, strategic choice is the primary } \\
\text { motive of banks engaging in CSR. }\end{array}$ \\
\hline $\begin{array}{l}\text { Bruyaka et al. } \\
(2013)\end{array}$ & Pharmaceutical & $\begin{array}{l}\text { Schwartz and } \\
\text { Carroll's } \\
\text { (2003) three- } \\
\text { domain } \\
\text { approach to } \\
\text { CSR and the } \\
\text { literature on } \\
\text { strategic CSR }\end{array}$ & $\begin{array}{l}\text { Qualitative and } \\
\text { quantitative }\end{array}$ & USA and EU & $\begin{array}{l}\text { The drivers of corporate } \\
\text { social responsibility (CSR) } \\
\text { activities in orphan drug } \\
\text { markets and the extent to } \\
\text { which biopharmaceutical } \\
\text { firms engage in these } \\
\text { activities with a strategic } \\
\text { orientation. }\end{array}$ & $\begin{array}{l}\text { Both US- and EU-based companies engaged in } \\
\text { orphan drugs development perceive their } \\
\text { involvement as a responsible business activity } \\
\text { beyond the economic dimension of CSR. } \\
\text { However, for the majority of these companies } \\
\text { CSR activities are not strategic according to the } \\
\text { criteria established in the literature. There are } \\
\text { differences between larger and smaller firms in } \\
\text { their use of CSR. }\end{array}$ \\
\hline
\end{tabular}

Source: Authors. 
1

2

3

4

5

6

7

8

9

10

11

12

13

14

15

16

17

18

19

20

21

22

23

24

25

26

27

28

29

30

31

32

33

34

35

36

37

38

39

40

41

42

43

44

45

46

47

48

49

50

51

52

53

54

55

56

57

58

59

60 